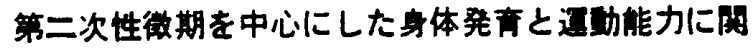 する研究 (第 5 報)}

九州大学 中原和夫， ○藤本奏雄. 滗口 鄉 野口博敏, 岡部弘道, 小林 篤 柴恒洋子

鹿児岛大学野口義之

研究は着手以来 5 年を経過し，我々の被験者は本年を 以て義務教育を終える。毎年 7 月上旬から下旬にかけて 測定プログラムの編成，旅行日程，用を工夫し，一日 一日の天候に高曋した。

研究の第一段階を終之て感概深いものがある.以下第 5 年次の成績を中心にしながら検討を加えることにし たい。

A. 身体発育について

に）長育13才児にみられた男罗の身長における借 位は14才を迎えて更に增大し, 主対象姾の浜の男女間 にはほぼ $3 \mathrm{~cm}$ の差か存している。年間発育染も男子 :06.82\%に対して女子は101.82\%と低い，10１2才昌に 見られた女子の位位は完全に少位となつて現れたのであ る.この傾向は当然下肢長にも現れている。姪の浜の男 女の差は約 $4 \mathrm{~cm}$ で $1 \%$ 品水準で有意である. 年間発有率 男子の $105.26 \%$ に対して女子は $101.69 \%$ と身長と同傾向 を示している，長育にお汁る女子の成長がやや停漁し た時期に，男子の発育は急敏に增加するのである。

1)幅厚育 胸囲 14 才の測定値は五家痤を除いて総 べての地域共に男子が侵れている. 主対象姪の兵の男女 差は $1.4 \mathrm{~cm}$ であり，作開発育率も男子の $106.21 \%$ に対 して $101.93 \%$ と女子が低い，な打姪の浜上大岛の女子の 作間発育率は共通して低く，この地域が共に来潮の早か つたことと関連して考察するとき，女子の胸囲の発育は 月経初潮時を中心纪念激に発育し, その後はやや停滞を 示すものであらうと推定される。

上腕最大曲は五家垽，立界の両地域に女子の優位が見 られる.この地域は家庭労䣦の激しい地域であつて，上 腕最大团の修練による可塑性を示するのと考えられる。 姪の浜についてみるに12,13 寸と女子の湘定值は男子 に傮社年間発育率もまた12才の女子は男子を淩㽞して いたのである.13，14 才と次第に男子の発育率が上犁し ている。

下腿最大囲は胸罒，上腕最大用とほぼ同様に 12〜13 才亡で女子の成績が優れている，14 才では五家荘，玄界 の女子がやや優れ，姪の浜，波多江は同位であり，大島 はやや劣つている，姪の浜沉ついて年間発育率を娭討寸 れば $11 １ 2$ ，1 专と来潮期に女子が高く14才では男子
が同い值を示している。

14 才の体重は五家荘を除いてすべて男子が高く、これ までの発育率も幅有とほぼ同様の現象を示している.

ローレル指数は男女共に都市である经の深低く保地 に高い. 特に五家荘，大岛の女子は高い値を示してい る. 娃の浜の男子か: 14 才に至つてな指数の低下の㑯 向を示すのはその長有が幅厚有を衮駕しているものと考 えられる.大島の男子の指数值が此較的高いことは，こ の地域の発青の停滞を示するのと考えられる。

\section{B. 運動能力}

1）筋力運動能力のうち筋力の男女恙は最も著しいも のの一つである、しかしこれとてもその年間発育率を検 討寸れば10才から12才までにおいて女子の優位が認め られるるのである.14才の握力はすへでの地域共に男 子が高く波多江，立界を除いて1\%水淮で有意差が見ら れる. 立幅跳も発育率においてはは注同様の傾向を示し たか，女子の $13 ， 14$ 才に执いて前年比マイナスの現象 が見られる．このことは女子の同時期におけ忛重增加 々脚筋力との関連において理解しなければならないであ ろう.このような能力の修練の時間的な問題か忘却され てはならない。

11) バランス，バランスの能力は12才迄全地域共に 女子がすぐれていた，13才に至つてこの傾向は崩れ， 14 才には更に著しく不均一な現象を示している。姾の 浜についてみるに13才に至つて男子が優れ14才るつつ いている.我々の測定方法が片足爪先立ちである点から 脚筋力の增大による影筫を考慮に入れて結果を読せへき であららと反省している。

III) 器用さ 走形式を伴うむの(アジリテイーラン) では年令と共に男子の優位が明らかとなる。このことは 先にも述へた通り筋力領域化括忛る男子の優位が投影寸 るものと考えなけ虬ばならないであろう．この能力の頭 著な発達はむしろ我々の判定開始以前にあるのではない かと考えられる．14 才の測定成精はすべての地域共男 子がすぐれている。サドステッブの男女差はアシシリテ イーランに比べて縮少され，五家荘ではむしろ女子が優 れ，その他の地域に执いてもその差は僅少であるか年令 によつては女子が優れている。

N) 体柔軟度 前屈機能計に上る体柔軟度湘定の成塂 は各年令を通じておおむね女子が優れている，労鹳過多 地域（五家荘，立界）の男子に特にこの能力の低下が見 られることは注意しなければならない（持久力以下九州 大学体育学研究 Vol. 5 , No. 5 に). 